\title{
From Caciques and Godfathers to Second-Order Corruption
}

Caio Coelho Rodrigues - Fundação Getúlio Vargas - Escola de Administração de Empresas de São Paulo - Brasil.

Amon Barros -University of Essex, Essex Business School, Colchester - United Kingdom

\section{Corresponding author:}

Caio Coelho Rodrigues

Address: Rua Itapeva, 474. Bela Vista, 01332000 - São Paulo, SP - Brasil

Phone: +55 (11) 964399136

E-mail: caio.rodrigues@gmail.com

We thank CNPq (Conselho Nacional de Desenvolvimento Científico e Tecnológico) for supporting and financing this research. We also want to thank the anonymous reviewers for the important contributions made during the reviewing process.

\begin{abstract}
The Carwash corruption probe has had a significant impact on what we know about systemic corruption in Brazil. Through the Odebrecht case, it is possible to advance organizational corruption theories by seeing how power has been abused over the years to create a systemic and enduring corruption system. Inspired by grounded theory, we simultaneously collected, codified and analyzed public documents from the plea deals of Odebrecht executives. From the empirical data, it is possible to see how second-order corruption has changed rules and norms in Brazil. We show that this kind of organizational corruption can be achieved by the abuse of relational power. We also demonstrate how second-order corruption is more difficult to combat, it normalizes corruption at a structural level, making it appear commonplace, the norm. Moreover, individually, it makes people rationalize corruption and distance themselves from the act ethically.
\end{abstract}

Keywords: Power and Politics, Organizational behavior, Deviant/Counterproductive Behavior, Ethics, Developing Countries

\section{Introduction}

The Carwash corruption probe is the 'Largest investigation of corruption and money laundering Brazil has ever had' (Brazil, 2014, p.1). From March 2014 to May 2019 the investigation went through sixty-one phases, tackling a corruption scheme involving public officials, directors of state-owned enterprises and private companies. Managers from private companies bribed executives from the Brazilian state-owned oil company, Petrobras, and other public agents in exchange for advantageous contracts. The scheme involved money laundering and illegal activities in other countries, such as the United States, Switzerland, Angola and Colombia (Brazil, 2014). 
Odebrecht was the largest private construction company involved. We analyze judicial documents from the investigation and the legal process to understand the relationship between Odebrecht and the Brazilian state. However, we do not consider the veracity of the crimes committed but investigate how the corrupt actors see the corruption process. In this sense, we do not judge or attribute crimes to the collaborators or to the people cited by them. Also, we only analyzed collaborations that were homologated by the Brazilian Supreme Court. However, their description of the company strategy and their perception of the corruption phenomena can enlighten corruption theory and show a glimpse of how corruption works inside an organization. We argue that the use of the collaborations, even though they are interested discourses, allow us to get information directly from corruption agents, which is known to be difficult in the fieldwork of corruption researches (Jancsics \& Jávor, 2012).

Lange (2008) argues that corruption studies often focus only on the individual or structural features of illegal activities. However, it is still necessary to develop a comprehensive view of corruption (Nielsen, 2003; Yu, Kang, \& Rhodes, 2018). Zyglidopoulos (2016) defines secondorder corruption as individuals abusing their power to change norms for their benefit. Nonetheless, the power to change rules does not depend only on position or authority, but on relationships with others. With this in mind, we build upon second-order corruption theory by identifying that the powers being abused in the corruption cases are relational (Fleming \& Spicer, 2014).

Frequently, organizations are unwilling to open their doors to researchers of corruption due to the illegal nature of these activities. Thus, reliable data on corruption is hard to find, especially considering that corruption agents are producers of those data (Arellano-Gault, 2019; Campbell \& Göritz, 2014; Nielsen, 2003). While second-order corruption is well defined in the literature, there is still room for development. We look at what kind of power is abused to change norms and how this perpetuates misbehavior and corruption (Graaf, 2007; Zyglidopoulos, Hirsch, 
Martin de Holan, \& Phillips, 2017). Using qualitative methodology, we identify the role of agents who occupied two key positions in the relationship between the Brazilian state and Odebrecht. On the state side, officials and politicians were the 'political chiefs' $\left(\right.$ caciques $\left.^{1}\right)$. On the company side, managers who have an established relationship with politicians are called 'godfathers'.

We highlight that the relationships between godfathers and caciques are central to understanding how second-order corruption takes place, creating and changing norms in their favor. People who occupy those positions have a considerable level of the individual agency; however, their position among various relationships with political parties, other businesses, and public officials also binds them. The abuse of this relational power is at the core of secondorder corruption. From their position, one can trace a network of personal bonds between public and private agents. They exchange access to power and favors for campaign donations and other forms of bribery that evolve into second-order corruption. Changes in norms and rules for their benefit also have the normalization and rationalization of corruption as both structural and individual consequences, respectively.

Most definitions of corruption highlight the fact that agents in positions of power seek personal gain (Anand, Ashforth, \& Joshi, 2004). However, our study shows that caciques, or political chiefs, and godfathers had a more nuanced and complex relationship. They sometimes seek personal profit, but at the same time, they always looked after the interests of their organizations, especially those of the company and the political party but also their informal network of operatives. It is not enough to understand their actions by focusing only on their individual gain. It is also necessary to take how they collectively profit from violating rules (Palmer \& Maher, 2006), taking into account the change in organizational and state norms. 
We reveal that second-order corruption is created by personal relationships that form a network which allows power to be abused. We discuss power in the management literature, social exchange and its relationship with corruption. Sequentially we present our methodology inspired on grounded theory and analyze the data we gathered to develop the theoretical advancement, making propositions based on our findings with a case study of Odebrecht. Finally, we present our conclusions, limitations, and ideas for future research.

\section{Power by structure and social exchange}

Following Zyglidopoulos' (2016) definition of second-order corruption, we look at the concept of power and how it relates to the corrupt practices which abuse it. For our purposes 'Power is having the discretion and the means to asymmetrically enforce one's will over entities' (Sturm \& Antonakis, 2015, p.139). Power is also related to dependencies in human relations, whether structural or individual (Morgan, 1986).

Pagès, Gaulejac, Bonetti, \& Descendre (1998) show that organizational practices went from a traditional system of personal exploitation to a dynamic in which the organization, through its structure, culture, and practice, became a source of domination and a holder of power. Organizations are structures that support those positions of power. However, individuals are actors with the power of agency (Clegg, 1989). Thus, it is necessary to acknowledge the existence of power beyond positions of authority and within human institutions. We seek to explain how power and its abuse enables acts of corruption.

Power can influence actions and will (Lukes, 1974). Organizational structures and individual power have a dialectical relationship (Lukes, 1974). However, the capacity to exert power is influenced by the position occupied within a structure and its network of connections. Therefore, this type of power only exists in a given relationship inside organizational structures (Clegg, 1989). 
Once power is exerted, it is manifested through rules and domination, reaching social structures and individual actions (Backhouse, Hsu, \& Silva, 2006; Davenport \& Leitch, 2005). This contingent approach is similar to the process of how corruption becomes a norm and changes rules for private benefit. Once second-order corruption is in place, new rules are created and corruption starts to be normalized, the same way that power can be observed in social structures (Nelson, 2017; Zyglidopoulos, 2016).

Fleming and Spicer (2014) identify four facets of power. (1) The coercive form makes someone do what would not be done if there were no power relationship. (2) The manipulation facet is composed of rules and norms constructed in the face of the performance of power. (3) Domination consists of the construction of ideological and dominant views. Finally, (4) subjectivation is the change of self, identity, and emotion. Each of these can be seen in the sites of organizational power (within, through, over and against organizations). The power within organizations is exerted in the formal limits of influence and capacity of organizational change. Power through organizations occurs when the organization is used for certain interests. Power over organizations is identified as a situation in which one has power or control over an entire organization. Finally, power against organizations is identified as attempts to threaten the organizational status quo (Fleming \& Spicer, 2014).

The power of manipulation is specifically related to rules and norms (Fleming \& Spicer, 2014). Sturm and Antonakis (2015) develop a model of interpersonal power in which individual, group, organizational and country factors serve as moderators to the use of power to harmful outcomes. The authors suggest that researchers should focus on the study of different types of power, its psychological aspects, and institutional underpinnings. We approach those aspects with an empirical study and look at the interpersonal power with that multilevel approach. In this sense, the individual power of an agent may be accessed by other agents. 
From these two frameworks, we can investigate political and organizational power from an individual perspective. Political chiefs and executives had their respective power given through their position in the structure. Executives have coercive power over their subordinates, manipulate rules inside the organization, and create or disseminate culture as leaders. Corruption becomes normalized inside the organization when middle and low levels accept it (Jávor \& Jancsics, 2013). This idea is well conceptualized in the assumption that corruption is socially constructed (Warburton, 2013). Therefore, it grows within a network through interaction between individuals (Kim \& Lee, 2019).

Political chiefs also have individual power due to their position in political party structures and their role in the distribution of campaign donations; also, the ideology of the party moves the group towards their goal. While both political chiefs and executives have personal power within their organizations, their relationship is complementary, that is, they can use the position of other for personal or organizational gain. In other words, executives have the ability to choose and deliver contracts in the interest of politicians and they could make campaign donations and bribes, thereby ensuring influence over the next election (Aggarwal, Meschke, \& Wang, 2012). Political chiefs, from their end, could hand out contracts and adjust norms to benefit the company (Reeves-Latour \& Morselli, 2017). Those are complementary powers to be abused and exchanged in a corrupt relationship.

The asymmetry of power between organizations has been studied in business-to-business relationships (Nyaga, Lynch, Marshall, \& Ambrose, 2013). However, we aim to contribute by highlighting the aspects of power that individuals can abuse. In that sense, we look at how individuals in positions of power and their relationships can change norms and rules to their benefit. So, we define relational power as the ability to access and use the power of another person through a symmetrical relationship. Note that both agents have different powers and they can exchange them through their mutually beneficial relationship. 
Power is in relationships between individuals as well as in systems, structures, ideas, and identities, albeit less perceptible (Pagès et al., 1998). Power can be enacted in many forms inside organizations and to different objectives (Fleming \& Spicer, 2014). It puts structure, position and agency combined and acts among social relations. We bring the framework of social exchange from Fiske (1992) to help explain the interactions between individuals into relational power examples. By combining Fiske's (1992) model with the model proposed by Fleming and Spicer (2014), we look into individual social interactions and the faces and places of power that emanate from this relational power.

Fiske (1992) proposes that all human interaction can be described as one of four types of sociality. (1) Communal sharing is when people contribute what they can in a pool of resources and get the amount they need without keeping track; such relationship is ideally eternal. (2) Authority ranking is when social interactions occur along hierarchies where the superior has power over the subordinate and at the same time is responsible for the decision making and distribution of resources. (3) Equality matching is when people exchange in equal parts and are always compensated for what they get. Finally, (4) market pricing describes relationships where people obtain access to resources for an accorded price.

Fiske's (1992) model was studied alongside issues of power, especially authority ranking relations (Schubert, 2005). In that sense, most studies deal with hierarchy and positions of authority and the abuse of that authority (e.g., Aguilera \& Vadera, 2008; Fath \& Kay, 2018; Rosenblatt, 2012). We contribute to a less researched idea that two individuals in powerful positions can have relational dependencies and engage in corruption due to their complementary sources of power (Warburton, 2013). It is true that they coerce, manipulate, dominate or change the identities of others in some of the four organizational places. However, it is the exploitation and abuse of communal sharing, equality matching, and market pricing in the social exchange between two people with different powers that enable that coercion. 
By combining both models we can define relational power. Both agents have power given by their own position in the structure. However, their relationship and exchanges create power that has a practical effect both inside and outside the relationship in the form of social interaction, faces and places of power (Fiske, 2004; Fleming \& Spicer, 2014; Schubert, Waldzus, \& Seibt, 2008). Corruption occurs when this relational power is abused for individual or organizational benefit. That said, it is possible to see how corruption stems from the abuse of power to create norms and rules.

\section{Corruption and abuse of power}

A classic definition of corruption describes it as conduct by a public official that deviates from their roles in pursuit of personal gain. However, this conceptualization only considers the role of public agents (Brei, 1996; Nye, 1967). Corruption emerges from the relationship between public and private agents. It appears when individuals act for personal gain but also to maintain their position inside a larger network, undermining the public good.

An axis from the individual to the structural level can be traced. Pinto, Leana, and Pil (2008) discuss this difference between organizations of corrupt individuals, when the beneficiary is an individual, and corrupt organizations when the beneficiary is the organization itself. Between them, there is a corruption threshold, a point from which combating corruption requires a systemic approach that changes organizational processes (Pinto et al., 2008).

We saw that power develops within relationships between individuals and the structures in which they participate. Corruption is the abuse of this power. In this sense, '[t]he focus on individual and organizational/societal attributes has led researchers to neglect an important additional consideration: relationships among actors' (Brass, Butterfield, \& Skaggs, 1998, p.14). This argument also corroborates the multilevel approach focusing on relationships (Moliterno \& Mahony, 2011). Corruption is a process that is engaged in by collectives in a network relationship, rather than only individuals (Nielsen, 2003; Palmer \& Maher, 2006). The 
multilevel approach aids the study of both the individual and the structural phenomena, in a system of corruption (Jancsics \& Jávor, 2012).

In describing the corruption network, it is possible to understand how companies interact with the state and build their systemic relationship. Complex corruption cases are based on the safeguards given by friendship and family ties; they eliminate market competition, a natural form of combating corruption (Husted, 1994). Agents form a corruption network by collusion (Borgatti \& Foster, 2003; Brass et al., 1998). The idea of established networks is key to understanding how executives collude with politicians.

This kind of networked corruption can be called cronyism, which is a specific type of corruption where private agents make recurrent payments to public officials, in this case, to change norms in their benefit (Dobos, 2017; Khatri, Tsang, \& Begley, 2006). The concept of crony capitalism is well established in Brazil with the idea of personal relationships between executives (Lazzarini, 2011; Reeves-Latour \& Morselli, 2017). However, Operation Carwash reveals that this network could involve politicians and create rules in favor of corruption activities (Carazza, 2018; Castro \& Ansari, 2017). Therefore, cronyism as exchanges between personal acquaintances develops into second-order corruption in a network system.

This network development of cronyism goes beyond simple transactions of power or resources. Politicians have access to regulatory power and public contracts, while businesspeople have money to make campaign donations and are interested in public contracts. Their social exchanges over time developed into a network of collusion and systemic corruption that goes beyond equality matching, giving them individual and organizational benefits (Fiske, 1992). What may have started as cronyism developed into systemic organizational corruption (Nielsen, 2003; Pinto et al., 2008). 
While corruption activities depend on the power held by individuals, it is the relationship between individuals with different powers that allows abuse of relational power. This merges Zyglidopoulos' (2016) definition of second-order corruption with Pinto et al.'s (2008) idea of a corrupt organization. The corrupt organization (where processes are corrupt) results from the abuse of relational power to change rules (Fleming \& Spicer, 2014).

Going deeper, corruption creates norms to benefit agents or organizations (Pinto et al., 2008; Zyglidopoulos, 2016). Power, as we saw, is reified in rules that become accepted (Lawrence \& Suddaby, 2006; Nelson, 2017). As Barley and Tolbert (1997) note, agency power creates, maintains and transforms institutions, and rules are specific aspects that turn common behaviors into mandatory courses of action (Lawrence \& Suddaby, 2006). Thus, second-order corruption normalizes misbehavior, thereby transforming acts of corruption into rules.

Normalization leads to the rationalization of corruption. Rationalization is the search for redemption from an act that is morally wrong (De Klerk, 2017). It creates excuses to gain ethical distance. According to Zyglidopoulos and Fleming (2008), this ethical distance is a path in the 'continuum of destructiveness'. Individuals go from innocent bystanders to guilty perpetrators, passing by innocent participants and active rationalizers by getting closer to the corrupt act, until effectively they are either doing it or denouncing it (De Klerk, 2017; Tenbrunsel \& Messick, 2004).

De Klerk (2017) describes the types of rationalization and unconscious motives for it, arguing that corruption agents may seek redemption by displacing responsibility, making an allegation of legal ignorance, minimizing consequences, refocusing attention to other problems, making social comparisons, feeling entitled to corruption, appealing to higher loyalties and rationalizing their intention. If corruption becomes normal, agents rationalize and perpetuate unethical behavior (Tenbrunsel \& Messick, 2004). 
By adding the idea of power to recent developments in corruption theory, it is possible to see that corrupt organizations can be systemic and hierarchically established; they abuse relational power to change norms for private benefit. The consequences of this power through organizations are the normalization and rationalization of corruption. These statements make sense in theory; however, they must be grounded on empirical bases. To this end, we conducted a study with a Brazilian case of systemic corruption that involved executives and politicians in collusion to change norms and rules to their benefit.

\section{Method}

Odebrecht activities mainly involve construction contracts but also public concessions, fuel refineries, the real estate sector, and engineering solutions. Although the company started in Brazil in the 1940s, it currently operates in fourteen countries and has expanded its business in close association with governments, through public contracts and funding (Rêgo, Dib, \& Bemvindo, 2016). Its probable involvement with corruption has already been implied through other high profile scandals involving politicians at the federal level (Valente, 2016). However, those scandals did not have major consequences for the organization, and the firm maintained its relationship with the government without changing its strategies.

Odebrecht has a lasting relationship with governments and was implicated in, at least, two corruption investigations before the Carwash. This history had concrete effects on rules and norms. Therefore, the size and time span of the case allow us to describe how power has been abused, enabling norms to be changed, both within the organization and outside of it. Secondorder corruption had already established cultural and institutional norms during the years of involvement between Odebrecht and the public sphere. That is why Odebrecht is an extreme example of a case study that can develop the concepts of systemic and second-order corruption, empirically demonstrating how the abuse of power can change rules. 
A qualitative case study is appropriate to improve second-order corruption studies, given that there is a need for empirical studies on this theme, and to gather data produced by corruption agents. After defining the concept of second-order corruption, researchers need to explore how the concept works and which power it implies. To do that, the qualitative approach is suitable because it empirically explores the mechanisms that can change norms and rules in an extreme or unique case (Eisenhardt, 1989). More specifically, the description of the Odebrecht case can give insights and generate propositions from its uniqueness to be further developed in future studies (Yin, 2003).

We used qualitative data from the Carwash judicial processes, such as testimonies, inquiries, petitions and, more importantly, the results of plea bargains (Delação premiada), a judicial process in which the defendant agrees to denounce other crimes and people to reduce their sentence by providing evidence. While 77 executives made plea bargains, we read through 55 of them that had their testimonies available. We chose to deeply analyze three key executives because they were from the upper echelons of the company and had knowledge of the whole scheme. Their collaborations allowed us to understand the various dialogic processes between caciques and godfathers. They were also the longest testimonies in the collaborations, with the largest level of support documentation for different cases that are now being investigated.

The choice of these three executives was due to their decision-making power within the company; the relevant and complementary information they supplied on various cases; and the use of those testimonies to start a high-profile investigation into Brazilian federal government politicians. Most of the other 52 executives were from the middle or lower levels of the company, their testimonies were smaller and related to specific crimes, not on how the entire corruption scheme functioned. In summary, those three executives and the key positions they held complement each other, describing how the abuse of power changed norms - both inside and outside the organization. 
The data are composed of various texts, audios, transcripts, videos, and documents. We decided to use grounded theory techniques to code and retrieve information from the data with the support of a Computer-Assisted Qualitative Data Analysis Software (CAQDAS). In total, we codified 422 written documents and 25 hours of video testimonies, all of which were sourced from the plea bargains and the judicial processes.

The qualitative approach enables this in-depth description of associations between various actors but maintains focus on key agents and aspects of the corruption system (Eisenhardt \& Graebner, 2007). The case covers the need for empirical studies of second-order corruption in an in-depth analysis, contributing to theory building in organizational corruption studies (Transparency International, 2017; Zyglidopoulos \& Fleming, 2008).

The analysis commences with the public videos of depositions. The coding of videos was done by marking the time of beginning and end of a video section, transcribing that passage, and coding to identify it. The use of this type of data requires an initial view and cataloging, and later, an in-depth analysis (Heath, Hindmarch, \& Luff, 2010). The textual documents and further evidence were analyzed alongside the respective videos to gain a better understanding of the matter. All data was in Portuguese, therefore we translated it after the analysis to present the results. We tried to keep the meaning of the sentence and the phrasing of the collaborators as close as possible to the original.

The CAQDAS was used in the process of collecting, codifying and analyzing data in different formats (Bringer, Johnston, \& Brackenridge, 2006; Charmaz, 2000). Through coding, it was possible to reconstruct the characteristics of the actors from Odebrecht and from the State, as described by the collaborators. We portrayed characteristics of their relations, such as money, friendship, jobs, history, interlocutors and intermediaries. It was possible to see patterns of relationships between a company executive and a politician. We were able to describe the case 
of Odebrecht as our unit of analysis and how the corruption activity worked through examples of abuse of relational power and the use of corruption culture in the company, with specific rules and sectors created to make illegal payments.

Inspired by the grounded theory, the process of coding the material started with two major groups of codes. One that described the crimes and processes and the other more thematic and theory-based.

The first group of codes explained the corruption scheme and process inside and outside the organization, the names of the people involved, and the case being denounced. These codes revealed how corruption had worked empirically, also they highlight the cases we describe in the analysis section. More specifically, these codes demonstrate how the collaborators described the creation of the caciques and godfathers strategy, how they created the structured operations sector and made the illegal payments and the results of their actions within and outside the company such as paying for laws and the creation of organizational rules. From these codes, we were able to select the events to be presented in the analysis section and to divide them into changed rules from within and outside of the organization.

The second type of code relates to theoretical insights such as the presence of power, personal relationships, a culture of corruption, etc. In this sense, these codes occurred in more than one case described by the collaborators; therefore, they contribute to the foundation of our propositions. The codes emerged from the description and comparison of events, revealing recurrent facts and actions. These were coded depending on how they were related to the functioning of the corruption system. The case descriptions from the three collaborators allow us to tell their stories from different perspectives on the same corruption cases. These codes could also be grouped into categories directly related to the theory. This second type of code emerged from the data and their categories can be seen in table 1. 
Table 1: Second group codification process

\begin{tabular}{|c|c|c|c|c|}
\hline Categories & Definition & Codes & Explanation & $\begin{array}{l}\text { Quote Example (Collaborators } \\
\text { testimonies) }\end{array}$ \\
\hline \multirow{3}{*}{ Power } & \multirow{3}{*}{$\begin{array}{l}\text { Group of } \\
\text { codes related } \\
\text { to the abuse } \\
\text { of power for } \\
\text { individual or } \\
\text { organization } \\
\text { al gain }\end{array}$} & $\begin{array}{l}\text { Personal } \\
\text { Relationship }\end{array}$ & $\begin{array}{l}\text { Close relationship } \\
\text { with people that } \\
\text { could give access } \\
\text { to power }\end{array}$ & $\begin{array}{l}\text { 'Both people had the power of } \\
\text { influence in the political system' }\end{array}$ \\
\hline & & Expectations & $\begin{array}{l}\text { Relationships } \\
\text { based on } \\
\text { dependency and } \\
\text { expectations } \\
\end{array}$ & $\begin{array}{l}\text { 'The more he sees that you are } \\
\text { helping, the more you create an } \\
\text { expectation for the next election. } \\
\text { It is a fluid thing' }\end{array}$ \\
\hline & & Trust & $\begin{array}{l}\text { Relationships of } \\
\text { trust }\end{array}$ & $\begin{array}{l}\text { 'So, he [executive] was supposed } \\
\text { to have a close, trusting } \\
\text { relationship with [political } \\
\text { agents]' }\end{array}$ \\
\hline \multirow{3}{*}{$\begin{array}{l}\text { Second- } \\
\text { order } \\
\text { corruption }\end{array}$} & \multirow{3}{*}{$\begin{array}{l}\text { Group of } \\
\text { codes that } \\
\text { describe the } \\
\text { creation or } \\
\text { alteration of } \\
\text { rules to } \\
\text { sustain } \\
\text { corruption } \\
\text { systems }\end{array}$} & $\begin{array}{l}\text { Structured } \\
\text { operations }\end{array}$ & $\begin{array}{l}\text { Payments through } \\
\text { the corruption } \\
\text { sector }\end{array}$ & $\begin{array}{l}\text { '[The payment was made] by the } \\
\text { slush fund system, operated by } \\
\text { the system of structured } \\
\text { operations of Odebrecht, in Cash' }\end{array}$ \\
\hline & & Bribery & $\begin{array}{l}\text { Payments for } \\
\text { direct returns such } \\
\text { as the approval of } \\
\text { laws }\end{array}$ & $\begin{array}{l}\text { 'From what has been explained to } \\
\text { me, a reduction of } 9 \text { million was } \\
\text { granted in exchange for the } \\
\text { payment of } 2 \text { million, having a } \\
\text { saving of } 7 \text { million, in an } \\
\text { electricity bill' }\end{array}$ \\
\hline & & $\begin{array}{l}\text { Public } \\
\text { contracts }\end{array}$ & $\begin{array}{l}\text { Corruption in } \\
\text { public contracts }\end{array}$ & $\begin{array}{l}\text { 'By allowing the market to be } \\
\text { organized [as a trust] there was } \\
\text { an illegal payment of } 3 \% \text { of each } \\
\text { contract' }\end{array}$ \\
\hline \multirow{3}{*}{$\begin{array}{l}\text { Normalizat } \\
\text { ion }\end{array}$} & \multirow{3}{*}{$\begin{array}{c}\text { Group of } \\
\text { codes that } \\
\text { makes the } \\
\text { corruption } \\
\text { appear to be } \\
\text { normal or } \\
\text { commonplac } \\
\text { e }\end{array}$} & Culture & $\begin{array}{l}\text { Values and } \\
\text { assumptions } \\
\text { shared within the } \\
\text { company }\end{array}$ & $\begin{array}{l}\text { 'Unfortunately, the culture was } \\
\text { created, we grew up thinking that } \\
\text { illegality and the question of } \\
\text { bribes each person accepts, which } \\
\text { type of payment' }\end{array}$ \\
\hline & & Rules & $\begin{array}{l}\text { Rules of the } \\
\text { company } \\
\text { regarding } \\
\text { corruption } \\
\end{array}$ & $\begin{array}{l}\text { 'Slush Funds were all generated } \\
\text { abroad' 'Everything done in cash, } \\
\text { always' }\end{array}$ \\
\hline & & $\begin{array}{l}\text { Information } \\
\text { technology }\end{array}$ & $\begin{array}{l}\text { Systems used to } \\
\text { corrupt activities }\end{array}$ & $\begin{array}{l}\text { 'It is the system that controls } \\
\text { illegal payments' 'It was not } \\
\text { supposed to exist' }\end{array}$ \\
\hline \multirow{2}{*}{$\begin{array}{l}\text { Rationaliza } \\
\text { tion }\end{array}$} & \multirow{2}{*}{$\begin{array}{l}\text { Group of } \\
\text { codes where } \\
\text { unconscious } \\
\text { redemption } \\
\text { of guilty } \\
\text { behavior } \\
\text { appears }\end{array}$} & Legitimate & $\begin{array}{l}\text { Excuse of } \\
\text { corruption act as } \\
\text { legitimate }\end{array}$ & $\begin{array}{l}\text { 'Even in the pursuit of legitimate } \\
\text { interest as I mentioned }[\ldots] \text { you } \\
\text { end up }[\ldots] \text { engaging in some } \\
\text { illegal behavior' }\end{array}$ \\
\hline & & $\begin{array}{l}\text { Better for } \\
\text { the Country }\end{array}$ & $\begin{array}{l}\text { Excuse of } \\
\text { corruption act as } \\
\text { good for the } \\
\text { country }\end{array}$ & $\begin{array}{l}\text { 'What exists today in the country } \\
\text { is a result of our initiative and } \\
\text { contribution' }\end{array}$ \\
\hline
\end{tabular}

Source: Made by the authors based on the collaboration reports. 
The stories, such as the relationships with various political actors, the corruption of the bidding processes and the payment of bribes to pass laws in Congress were compared with each other to look at the similarity and cooccurrence of codes, defining those deemed more important. The second stage of the analysis grouped these codes into concept categories. Power, rationalization, normalization of corruption and second-order corruption were the main ideas that formed our propositions when related to theory.

The constant comparison of empirical data with theory enabled the development of concepts on corruption and the analysis of the production of meaning by the actors involved in corruption. Thus, we understood how the executives reported the phenomenon (Glaser \& Strauss, 1967; Suddaby, 2006) and enhanced theoretical and empirical concepts.

However, all the documents used in this analysis should be considered as positioned discourses. They aim to produce certain effects on their audience. A plea bargain is part of a judicial process. The actors producing discourses and evidence have a vested interest in the results of their agreements with the judiciary. Leniency agreements and plea bargains are options that oblige defendants to contribute to the investigation (Brasil, 2011, 2013). However, judiciary documents may still be more truthful then what is exposed in the news (Shapira, 2016). While leniency is granted by administrative bodies, such as the Administrative Council for Economic Defense (CADE) and the General Controller of the Union (CGU), the collaborations are homologated by the Judiciary with the participation of the Public Prosecutor.

We acknowledge that the company and its employees were interested in reducing their sentences by admitting guilt and collaborating. They provided information on other people involved in the schemes and brought more detail to the cases in which they participated.

Some of the bias in the data was mitigated due to constraints of the process. The executives did not know what information the prosecutors already had. Nevertheless, it is always necessary to 
approach the data critically, and double-check to avoid opportunistic and individualist narratives, to appropriately correlate the facts, aiding broader comprehension of the whole process. For corruption cases and data on legal processes, it is important to critically consider the data during analysis.

Furthermore, it is not our role to accuse or condemn the collaborators. To avoid any injustice to the people involved and to respect their long-term rights in accordance and compliance with the suggestions made by an ethical research committee, we took care not to identify any of the informants. We also had to maintain a healthy level of skepticism regarding their stories.

Under those assumptions, the data is still valid as a description of second-order corruption. By approaching it critically, it is possible to see that the mechanisms of blaming the culture, the system or the company were part of a rationalization and normalization process that we included in our propositions. In that sense, the information we analyzed enabled the investigation of the mechanisms of corruption and how the collaborators pictured them.

Following procedures from grounded theory, we first present the case and its contexts highlighting organizational and state norms changed as a result of corruption. Then, we demonstrate how the empirical data help to build on the second-order corruption theory by drawing propositions (Strauss, 1987).

\section{Analysis and Discussion}

Odebrecht is the largest of the twenty-three engineering companies prosecuted in Operation Carwash that started in 2014 and continues to this day. The operation focus was on a corruption scheme that involved politicians, state-owned companies such as Petrobras and companies from various sectors. The plea bargain and the institutional readiness to combat corruption were key mechanisms used by the operation to grow (Castro \& Ansari, 2017). Among the arrested were businesspeople, lobbyists, politicians, former presidents, and others. 'It is not a matter of 
five years, ten years ago, we are talking about thirty years ago'. (Collaborator testimony²). The cases being investigated go as far as the 1980s and give us a picture of how corruption evolved into a systematic and incorporated practice in Brazil (Brasil, 2014).

The long-term relationships revealed by the operation show an increasing level of professionalism in corruption over the years. They helped to create organizational norms and laws in their favor. Due to the amount of data available on various episodes of corruption, it was not possible to present all cases in one article. In the analysis, we discuss the changes in norms inside and outside the company, as pointed by the collaborators.

To explain kinds of power related to changes of norms inside the company, we describe two stories: the strategy of personal relationships between caciques and godfathers, and the structured operations sector for illegal payments. To explain the changes outside the company we present three stories: the purchase of the presidential act (MP470); the agenda of policies between executives and political chiefs; and the Corinthians Stadium. We chose those cases because they were more contextual in the overall mechanism of corruption, they also had more facts and evidence to help give a better description from the points of view of the three collaborators.

\section{Changing norms inside the organization}

Firstly, we must define the agents and their position in the hierarchy. Brazilian caciques have access to power and influence over other politicians on a large scale (Roniger, 1987). 'That cacique matter was common, in every election, the caciques of the parties asked for resources for their support group' (Collaborator testimony). They operate in various roles within the political sphere of the country, either in government or in the opposition. Caciques receive campaign contributions from executives and distribute them inside the political party. In return, they grant favors to the executives using their political influence and network of contacts. Although in other countries caciques had a definition prior to this study, as a politician with 
great influence (Anderson, 1988; Choi, 2007; Nunes, 2003), we add to their role their responsibility for collecting and distributing legal and illegal money.

He acted as a collector of the first national [Party Name] campaign, party of which he was one of the founders; that this donation sought not only to strengthen the relationship of [the company] with [a politician] and with the new party founded, it was to create a differentiated relation next to the candidate who had an excellent relationship with the postulant to the presidency (Collaborator testimony).

On the company side, their contacts are called godfathers, which is a term commonly understood as having connotations of family or a close friend. 'Every person has a godfather in the house [Odebrecht] who is responsible for a given situation' (Collaborator testimony). The godfathers are responsible for maintaining personal relations with a political group, a specific political chief or the politically nominated president or director of a state-owned company. This godfather builds a personal relationship with his contact to maintain their system of corruption and influence over political decisions that favor the company, a type of lobby that buys votes from legislators through a personal relationship built with illegal money.

Basically, you always had, with all state-owned companies, a godfather, someone who dominated the relationship, internally or through an old relationship, or through the strength of the business. Other companies [than Odebrecht] also interacted with that company or that ministry or any public entity. (Collaborator testimony).

For the executives, to collaborate meant to lose friends, which shows how close they were with their contacts in the power structure.

I'm losing, in this collaboration, about 30 friends, one quality I have is that [...], every time I created a relationship with a person the relationship became personal. So, I'm losing 30 friends who, from tomorrow, from the time they read, they will call me a scoundrel to defend themselves. I use a phrase with my lawyers, that when the need comes in through the door, morals leap out the window (Collaborator testimony).

Even the presidents of the Chamber of Deputies and of the Senate had their godfather. He was an executive who had personal relationships with them both and influenced debates in Congress. Access to the presidents of the federal legislative bodies gave Odebrecht huge influence over the matters discussed in Congress, which means companies controlling institutional change as suggested by Zyglidopoulos (2016). The data show that the designation of this kind of relationship was strategic within Odebrecht, normalizing corruption in the 
company (Barley \& Tolbert, 1997). 'The person from the Odebrecht Group who had a relationship of trust with the caciques of the (Party name) of the House and Senate, including for bribery price negotiations, was (Name)' (Collaborator attachment text file)

Personal relationships enhance corruption and political chiefs oversee the distribution of legal and illegal campaign donations. This clientelism and cronyism result in political cliques at an individual level based on reciprocity (Brass et al., 1998; Roniger, 1987). It cannot be said that politicians or executives exerted more power. They both exercised power from their positions in the structure and their close relationship. Therefore, when they reached an agreement on campaign donations, some kind of counterpart was expected from the executive, in the same way when the politician changed laws or arranged contracts for the company, he expected some kind of monetary incentive, in a quid pro quo and friendship relation (Fiske, 1992). 'There was an expectation of contribution, whether it was aligned with specific counterparts or created an expectation, but it came from large, large values' (Collaborator testimony).

Within a larger network structure of those types of relationships, they needed to involve 'middlemen' and 'brokers' (Lemarchand \& Legg, 1972). These intermediaries, people chosen by politicians and executives, were responsible for fulfilling the agreement. Middlemen could be friends, family, politicians, employees, and even other companies who would agree on amounts and handle the negotiation. 'I cannot attest that we talked directly with her, it may have been with a middleman very close to her, the [politician] seeks to preserve himself and places a representative' (Collaborator testimony). Brokers are the people sent by executives and politicians to make the cash delivery or the currency exchange operation.

[He] was our biggest and closest operator. For security reasons and to avoid the risk of contamination with other companies, he was contracted exclusively to set offshore companies and carry out payments on our order, which were supplied by Odebrecht's undeclared offshore companies (Collaborator testimony).

Empirical data shows that the choice of each contact, between political chiefs and godfathers, was based on their relationships and company hierarchy. The higher the position in the 
hierarchy at Odebrecht, the more important the executive contact was in government. As predicted, this shows how power emanates not only from positions but also from relationships (Fleming \& Spicer, 2014). Thus, the corruption system has a hierarchy running parallel to that of the company. The CEO was responsible for Brazil presidential campaign, 'The CEO of Odebrecht SA, in this case, was not involved in state, municipal or other country campaigns' (Collaborator testimony). This means that inside the organization and the state there were relations of authority rank (Fiske, 1992), where subordinates receive orders from their superiors and are responsible for different political positions. However, each godfather had the autonomy to decide how much money they would donate to politicians, knowing that this money was going to be discounted from their projects and bonuses. Political chiefs had the role of distributing money to less powerful public agents.

The strategy of having a godfather for every cacique had consequences over the years. They created a routine of campaign contributions based on election years. Executives and politicians became friends. This created elements which normalized routines and enhanced the rationalization process. The collaborators often stated that it was the way of the company and that they had to exempt themselves from guilt (De Klerk, 2017).

'This was a problem that we had throughout Brazil because a vicious circle was created. I estimate that three-quarters of Brazilian campaigns were from slush funds' (collaborator 1). That number may be overestimated since other executives reported that only twenty percent of the donations were from slush funds, but that those numbers grew over the years. Nevertheless, it can be agreed upon that Brazilian campaign donations had a parallel scheme of illicit transactions (Carazza, 2018).

There were also structural changes inside the company. Odebrecht made most payments using a specific department responsible for collecting slush fund cash from different resource centers, 
then allocating it overseas to make the payment to people in the government. The model was created in the 1990s. In 2005, a new director improved the methods and the sector was nominated 'Structured Operations' allocated in the holding company. They intended to separate the source of the bribery from its distribution and distance the name of the company from the money via offshore companies and banks. The creation of this sector shows how the company structure, its norms, and culture were modified to enhance the corruption process.

\begin{abstract}
When the 'Modus operandi' of the slush fund generation and distribution was structured in the 1990s, the idea was to have a 'Wall of China' segregating the legal entity, that is, the corporate area, from the distribution team. Likewise, distribution should naturally be controlled by its financial system, checks, and balances. At that time, we believed that in doing so, we would avoid more distortion than letting each project/entrepreneur generate its own slush fund and distribute it through fictitious contracts, contaminating even the official accounts of the company. For this reason, the corporate executives of the group should not functionally relate to the people responsible for the distribution, and the payments through unrecorded resources were the sole responsibility of the people who authorized them. (Collaborator attachment text file)
\end{abstract}

The relationship between caciques and godfathers may start as cronyism, a specific type of corruption between bounded people (Dobos, 2017; Khatri et al., 2006). However, it developed into second-order and organizational corruption by changing rules, culture and processes inside the company. Godfathers and caciques had complementary and relational power to change the entities in which they were interested.

\title{
Changing norms outside the organizations
}

Some definitions of corruption describe a simple exchange of money for specific compensation (Nye, 1967). This type of bribery also occurred, for example, during the purchase of provisional measures $^{3}$ (MP). 'The first of them is the theme related to 'Refis da Crise' [...], in which I acted for the government to approve MP 470' (Collaborator attachment file). MP470 was one of the paybacks from a bribe of BRL 50 million (approximately USD 12.5 million). This measure provided an installment program for tax debts. While this is second-order corruption acting in federal laws, this behavior is treated by the company as a normal lobbying transaction (Jia, 2018; Nelson, 2017). According to the collaborators, MP470 could not exist the way it does if 
not for the spurious relationship Odebrecht had with the government. This exchange can be seen as equality matching where each one gets what they desired and the relationship ends there. It is worth mentioning that this kind of exchange was more common with low-level executives to gain public contracts, but as we see here it can also buy presidential acts (Fiske, 1992).

Almost every meeting I had with him, I would carry an agenda, [...] of demands, and at the end of the meeting, or in the middle, He would say, look, (Name), help me here, you have that payment you have to deliver. (Collaborator testimony)

Other specific private gains resulted from personal relationships, built over time, creating the expectation of future donations. Personal relationships, idealized as eternal, create a common pool of resources where executives and politicians may take what they need when they need (Fiske, 1992). That happened when one of the executives claimed to agree to give BRL 150 million (approximately USD 37.5 million) over time to a group of politicians in what they called an Italian Spreadsheet. This money could be requested any time after the agreement and, in exchange, the politicians would support the company in any way it needed in the future.

When it arrived in 2014, he expected me to add over 100 million. He had already used 50 million and expected more 100 million, why? Because I had a big agenda with him, we had constant meetings. (Collaborator testimony).

To the executives, these connections were based on a trinity of performance, personal relations and money, which gave them access to power.

\footnotetext{
The relationship between the person and the organization with a certain public agent is based on a trinity. That is, the performance, the organization's ability to deliver what is legitimate, what the governor wants, the president wants, investment and everything... the personal relationship, you build trust. And money to meet the interests, be it political or private of the person. (Collaborator testimony)
}

A long-term relationship was created and keeping track of the reward for the bribery or the donation became unnecessary in a communal sharing interaction (Fiske, 1992). They had a deal based on expectations. Godfathers expected access to power and to influence the political agenda. Political chiefs expected campaign contributions and bribes. This adds to the theory that the role of caciques is beyond that of merely distributing money, they also had their campaigns sponsored by executives who, with this relationship, prospered in their private 
organizations. The scheme established politicians and executives in positions of power for years. The relationship also sustained caciques positions and relevance within the parties.

It has always been clear that, the larger the agenda for the group's business interests and the more government support for our business demands, the greater the expectations and requests for 'financial support', supposedly intended for the elections. (Collaborator testimony)

In their collaboration, the managers put themselves in a situation where demands were legitimate. They had to pay for the state to do what it should have been doing anyway. That is a way of rationalizing corruption (De Klerk, 2017).

Even in the pursuit of legitimate interests, as I mentioned, the issue of the Corinthians arena, the Cuba issue, and other bills. That even, that's what I'm saying. They were legit, legitimate interests, you looked for, they were interesting. But in that process of interaction with the public authorities, you end up [...] engaging in some illicit behaviors (Collaborator testimony)

These payments influenced the state and privileged some sectors to the detriment of others. Politicians worked for themselves and specific companies. They had an agenda to discuss and resolve in exchange for money and expectations of campaign donations. However, they also had long term relationships that influenced their decisions. When asking the state for support in the form of loans to foreign projects, Odebrecht executives had the political influence, technical arguments, and lobbyists inside that were necessary to get the loan approved.

Although I said all our [government] loans had a 'technical basis'. Now it's important that we have people who warn us: look you're going to have a problem here, you'll have trouble there, you need that kind of guarantee. (Collaborator testimony)

For Odebrecht, the relationship with the state opened doors for investments, financing, contracts, concessions, and even internationalization (see Rêgo et al., 2016). Corruption was both individual and structural. The executives argue that the corruption network formed ties so strong that Odebrecht gave 3.7 billion dollars in campaign donations without any direct return, only favors, and agenda. They even participated in construction projects with no clear profit motive.

Corinthians stadium, where FIFA held the opening ceremony of the 2014 FIFA World Cup, is an example. Odebrecht claims to have built the stadium at the request of a politician, even though it could cause financial losses for the company. 'I think that in the end, we lose, 
Corinthians lose, the bank loses all. It is a game where everyone loses.' (Collaborator testimony). Its construction is part of an old relationship between two individuals with power positions both in the private and public sectors. By constructing the stadium, Odebrecht ensured that they maintained their position and access to power. 'Basically, a request from (Name), [who said] "look, help Corinthians to build the stadium." (Collaborator testimony).

Campaign donations and personal relationships are two facets of the affiliation between godfathers and caciques. Some of the Odebrecht requests to the government, especially those related to public contracts, needed technical arguments to win bids or approval for financing. To these ends they used partners, associations, lobbyists, often people within the government or chosen by a political chief, with power to build a coalition and present arguments to convince politicians or technically endorse their predefined decisions. However, this legal corporate political activity (CPA) is only one part of the entire process of patron-client politics. These CPAs were used to make the official request to the state, while personal and corrupt relationships granted the approval from behind the stage.

In our evaluation, the final result that she (the Lobbyist) generated was not anything (illegal), that is, she did not defend a loan that did not make sense, she did not defend something that had no technical background, but she worked. When I say she worked, for example, if we had a loan to put on the agenda and maybe that loan would take two or three meetings of the $C O F I G^{4}$, she helped us to advance the credit. [...] This loan has that kind of problem. Many times, you go, if you do not solve this issue you get kicked out of COFIG, you have to come back and order again, she already advanced it for us (Collaborator testimony).

In summary, the relationships worked between the executives at Odebrecht and members of the state by changing the organizational culture and structure. It occurred throughout the entire company hierarchy and in all government spheres. This huge interaction with the state, with numerous relationships within this model, built the systemic corruption network. The result was the change in public contracts, Brazilian laws, and company processes over the years.

\section{Back to Theory}


Zyglidopoulos (2016) defines first and second-order corruption from the idea that corruption is based on the abuse of power. We develop that idea, bringing together the theory of individual and relational power and corruption theory with the case study. From that, it was possible to offer three propositions $(\mathrm{P})$ that develop the precedents and outcomes of second-order corruption. In this section, we elaborate on those propositions and demonstrate the relationship between the constructs based on the case study and the theory. Figure 1 shows the constructs and propositions that relate to then to be further developed.

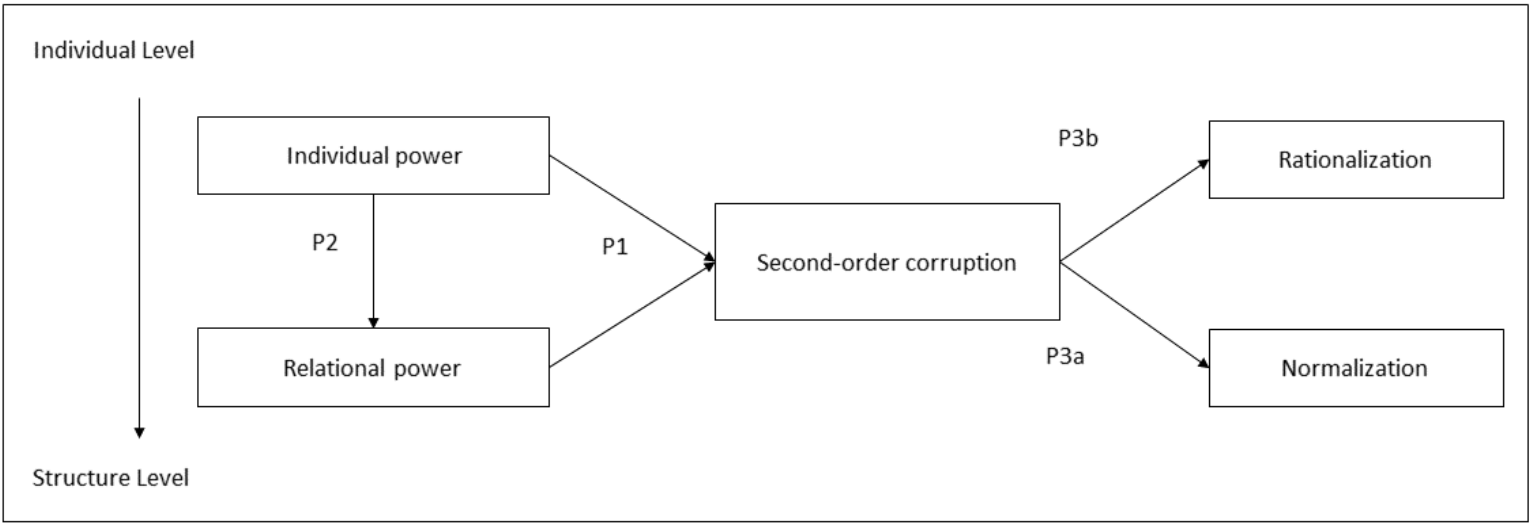

Figure 1: Constructs and their relations

Anand et al. (2004) state that corruption comes from positions of power or from the misuse of a public role (Nye, 1967). However, for second-order corruption, this abuse of power needs to change the rules to benefit the agents or their organization. Therefore, it is necessary to first define the kind of power that is being abused.

In the case of Odebrecht, every connection between the public and the private sector described in the collaborations points to a personal relationship. Consequently, these nodes only have decision-making power due to their position in the corrupt structure. From one side there is the godfather who relates directly with a cacique. He is responsible for getting the authorization of his superior, allocating the source of the money, and asking the structured operations sector to arrange the payment through a middleman. 'Part of this payment may have been via an official 
bonus (donations), [...], one part was slush funds, one part an offshore account' (Collaborator testimony).

The politician, on the other hand, is responsible for allocating this money to his partners and political associates and giving the company access to power. This access could result in specific compensation such as a provisional measure, or an extensive agenda with multiple types of political demands. That would benefit the company and therefore the executive.

The established relationships are forms used by the executives to gain access to the power of the state. The abuse of the power of the state over time creates second-order corruption because the state finds itself indebted to private sector control (Barley, 2007). Thus, second-order corruption is not the abuse of the position of the individual for their gain, but rather an abuse of power accessed through the relationship between individuals. Therefore, this type of corruption should be treated as a systemic and interconnected activity (Nielsen, 2003).

Second-order corruption is the corruption that changes norms to the benefit of individuals or organizations (Zyglidopoulos, 2016). However, organizational corruption is the corruption that cannot be ended if processes are not changed because they were compromised (Pinto et al., 2008). This definition overlap is seen in the example of caciques and godfathers that developed into changing organizational processes and state laws, transforming actions into structures (Barley \& Tolbert, 1997) they change entities, organizational and state norms (Sturm \& Antonakis, 2015). Therefore, it is possible to contribute to the definition of second-order corruption as in proposition 1.

Proposition 1: Individual agency and structural factors contribute to the change of norms, rules or processes in second-order corruption.

Empirically, it is possible to observe how corruption is a multidimensional phenomenon (Lange, 2008). Therefore, the research on corruption needs to consider the micro, meso and 
macro levels of analysis in a comprehensive and systemic view of corruption (Brass et al., 1998; Nielsen, 2003). Individual actions and relationships of power transformed cronyism into systemic corruption and gave place to structural changes that reified corruption in rules (Barley \& Tolbert, 1997; Khatri et al., 2006).

The power mentioned here is not only that inherent to authority, nor is it the ability to manipulate or coerce others to your will, causing them to do something they do not want to do (Lukes, 1974). The use of power here is a win-win strategy. It rests in the relationship of trust between a public and a private agent. Power is a relational aspect of their connection. It is not a coercive power, as both agents win from its abuse (Clegg, 1989; Fleming \& Spicer, 2014).

We argue that the abuse of power in second-order corruption is bigger than that given by an individual position. It is a power exerted on a network of complexity; therefore, to change norms for private gain, it is necessary to be connected, to be able to exert power over relationships and then abuse it. It is a manipulation of power in which individuals create or modify norms for their benefit through social interaction (Fiske, 1992; Fleming \& Spicer, 2014).

More important than the position they occupy are the structures and relationships of political chiefs and executives that allow power to be abused for private gain. Power is embedded in structures and human relationships (Fleming \& Spicer, 2014). Relational power is that which is abused, in collusion, to modify norms in second-order corruption, as seen in proposition 2.

Proposition 2: Individual powers can be exchanged to create relational power.

For years the corruption in Odebrecht brought the company closer to the government. The result of this scheme was massive control over government decisions but also the guaranteed continuation of politicians in their positions. This context of second-order corruption, created 
by the abuse of relational power, has two consequences that matter for organizational corruption. On the one hand, the corruption is seen as normal, because the structures around it are part of the habits of people, and it is not a single event, but rather an everyday relationship (Graaf, 2007; Nelson, 2017). On the other hand, the trust that is required for acts of corruption enhances personal relationships and results in the rationalization of corruption. The executives try to exempt themselves from guilt over doing the wrong thing, which also contributes to continued corruption (De Klerk, 2017).

Several examples can be used to describe how corruption has become normal in the routine operations of Odebrecht. 'All this [corruption], that is happening now, it was a thing institutionalized, it was a normal business' (Collaborator testimony). They used intermediaries and partners to carry illegal payments as part of the corrupt network. The structured operations sector was responsible for illegal payments. Executives of Odebrecht received their bonuses through the illegal system and could ask for illegal payments to gain specific advantages or maintain relationships. As Nelson (2017) argues, corruption becomes the norm when too many people get used to it. In those cases, a toxic culture is created. By creating a culture of corruption, the force of domination power is in place and establishes both ideological and preeminent views. The individual either accepts it or leaves (Fleming \& Spicer, 2014; Pagès et al., 1998). Second-order corruption, based on relational power, leads to normalization of corruption, as stated in proposition $3 \mathrm{a}$.

Proposition 3a: Second-order corruption reifies power into rules, normalizing corruption.

Proposition 3b: Second-order corruption leads individuals to rationalize corruption.

Finally, as seen in proposition $3 \mathrm{~b}$, the abuse of relational power also influenced the rationalization of corruption. The executives kept stating that their acts were necessary and legitimate and that they were doing good things for the development of the country. 'For the 
venture to be successful and to be concluded in time to generate energy for the needs that Brazil, we can say, demanded' (Collaborator testimony).

At the time of the collaboration process, the executives had already been found guilty and incarcerated. By collaborating they aimed to reduce their sentences, although the process of rationalization and deconstruction of rationalization was evident. They are now consciously aware that what they did was wrong, however, to redeem themselves from the guilt they created excuses, blaming the company and the structure. They also state that their actions were legitimate because they would benefit the company and the country.

Thinking about the context of corruption, and the continuum of destructiveness, the executives were in an environment of second-order corruption that made corruption a norm. They participated in corruption as guilty perpetrators. Their acts were propelled by their position in the organization and impelled by their culture (Zyglidopoulos \& Fleming, 2008). By rationalizing, individuals are engaging in a changing of self, giving unconscious excuses to act against their own morals. The power acting here is subjectivation, in the sense that it molds the identity and beliefs of individuals (Fleming \& Spicer, 2014). They attain ethical distance and are pushed through the continuum of destructiveness (Zyglidopoulos \& Fleming, 2008).

\section{Conclusion}

As Zyglidopoulos (2016) argues, second-order corruption is harder to address, because of its perpetuation across levels of hierarchy. However, the rules are changed by the abuse of relational power, and not only by the power of positions or authorities. We carried a single case study and found that individual agency and structural factors impact Second-order corruption; the social exchange of individual powers creates relational power; Second-order corruption impacts the normalization and rationalization of corruption. 
The use of qualitative methods with recent developments in power and corruption theories can be beneficial to systemic corruption research, given the necessity of empirical analysis of corruption (Nielsen, 2003). This study also enhances the definitions of caciques and godfathers, considering the Brazilian context, and highlights the relational power that those actors have within the structure. They are bounded both by the corrupt practices and the necessity of pursuing the interests of their organizations in a murky environment.

The abuse of power was a win-win strategy of power manipulation (Fleming \& Spicer, 2014). These long-term relationships between political chiefs and godfathers enabled them to have an agenda with the government without necessarily making payments for each of their demands. They were partners, and their association benefited the company and political operators to the detriment of Brazilian society. This description of a personal relationship is intended to demonstrate how the connection between two nodes of the larger network enabled corrupt acts by individuals but also framed their actions inside the overall corruption system.

Second-order corruption creates rules for private benefit; however, the power that is being abused is individual and relational. Internal mechanisms and cultures also are modified. Second-order corruption leads to the normalization and rationalization of corruption, pushing agents further into the continuum of destructiveness (Zyglidopoulos \& Fleming, 2008).

Odebrecht and the other companies were caught by Operation Carwash with the aid of plea bargain collaborations. Some of the mechanisms of corruption were dismantled such as the prohibition of campaign donations from companies since 2016. Despite the board president remaining the same, the president of the holding was replaced, the processes seemed to be changing, and they started a 'journey of transformation', as they called it (Odebrecht, 2018). However, many of the laws they purchased and the contracts they gained throughout the years 
of corruption still need to be reviewed. Those significant changes and forms of combat open future research questions.

The propositions are based on a single case study and current theories on second-order corruption and power. They can be developed and tested with future research. Corruption is socially constructed, and changes in norms, rules, and habits take time (Warburton, 2013). Therefore, a longitudinal study may be appropriate to investigate the effects of second-order corruption on rules and norms. Specifically, the idea that individual powers can be exchanged to be transformed into relational power may be key to understanding the growth of systemic corruption in the upper echelons of organizations. Also, the normalization and rationalization of corruption as possible consequences of second-order corruption needs to be further studied. Both are important concepts in combating corruption because if they are not addressed, they can lead to more corruption (Nelson, 2017; Zyglidopoulos \& Fleming, 2008).

\section{Footnotes}

${ }^{1}$ Some native Brazilians designate the chief of a tribe with the word cacique.

${ }^{2}$ Following the recommendation of the ethical committee and the juridical idea that people have the right to be forgotten (Weber, 2011), the names will remain confidential.

${ }^{3}$ Provisional measures (medidas provisórias): Similar to executive orders in the United States, these measures, signed by the president, work as law for sixty days and can become permanent with the approval of Congress.

${ }^{4}$ COFIG (Export Financing and Guarantee Committee) - Administrative body that monitors the operations of the Exportation Financing Program

\section{References}

Aggarwal, R. K., Meschke, F., \& Wang, T. Y. (2012). Corporate Political Donations: Investment or Agency? Business and Politics, 14(1), 1-38. https://doi.org/10.1515/1469- 
3569.1391

Aguilera, R. V., \& Vadera, A. K. (2008). The Dark Side of Authority: Antecedents, Mechanisms, and Outcomes of Organizational Corruption. Journal of Business Ethics, 77(4), 431-449. https://doi.org/10.1007/s10551-007-9358-8

Anand, V., Ashforth, B. E., \& Joshi, M. (2004). Business as usual: The acceptance and perpetuation of corruption in organizations. Academy of Management Executive, 19(4), 9-23. https://doi.org/10.5465/AME.2005.19417904

Anderson, B. (1988). Cacique Democracy in the Philippines: Origins and Dreams. The New Left Review, (1/169), 3-31.

Arellano-Gault, D. (2019). Government Corruption: An Exogenous Factor in Companies' Victimization? Public Integrity, 21(2), 141-160. https://doi.org/10.1080/10999922.2018.1433425

Backhouse, Hsu, \& Silva. (2006). Circuits of Power in Creating de jure Standards: Shaping an International Information Systems Security Standard. MIS Quarterly, 30, 413. https://doi.org/10.2307/25148767

Barley, S. R. (2007). Corporations, democracy, and the public good. Journal of Management Inquiry, 16(3), 201-215. https://doi.org/10.1177/1056492607305891

Barley, S. R., \& Tolbert, P. S. (1997). Institutionalization and Structuration: Studying the Links between Action and Institution. Organization Studies, 18(1), 93-117.

Borgatti, S. P., \& Foster, P. C. (2003). The Network Paradigm in Organizational Research: A Review and Typology. Journal of Management, 29(6), 801-830. https://doi.org/10.1016/S0149-2063

Brasil. Lei 12529/11 | Lei $n^{o} 12.529$, de 30 de novembro de 2011. , (2011).

Brasil. Lei 12850/13 | Lei $n^{o} 12.850$, de 2 de agosto de 2013. , (2013).

Brasil, \& Ministério Público Federal. (2014). Entenda o caso. Retrieved from 
http://lavajato.mpf.mp.br/entenda-o-caso

Brass, D. J., Butterfield, K. D., \& Skaggs, B. C. (1998). Relationships and Unethical

Behavior: A Social Network Perspective. The Academy of Management Review, 23(1), $14-31$.

Brei, Z. A. (1996). Corrupção : dificuldades para definição e para um consenso. 30(I), 6477.

Bringer, J. D., Johnston, L. H., \& Brackenridge, C. H. (2006). Using Computer-Assisted Qualitative Data Analysis Software to Develop a Grounded Theory Project. Field Methods, 18(3), 245-266. https://doi.org/10.1177/1525822X06287602

Campbell, J.-L., \& Göritz, A. S. (2014). Culture Corrupts! A Qualitative Study of Organizational Culture in Corrupt Organizations. Journal of Business Ethics, 120(3), 291-311. https://doi.org/10.1007/s10551-013-1665-7

Carazza, B. (2018). Dinheiro, eleições e poder, As engrenagens do sistema político brasileiro. Retrieved from https://play.google.com/books/reader?id=WONaDwAAQBAJ\&hl=pt_BR\&pg=GBS.PT 24.w.0.0.163.0.1

Castro, A., \& Ansari, S. (2017). Contextual "Readiness" for Institutional Work. A Study of the Fight Against Corruption in Brazil. Journal of Management Inquiry, 26(4), 351-365. https://doi.org/10.1177/1056492617696887

Charmaz, K. (2000). Grounded theory: Objectivist and contructivist methods. In N. K. Denzin \& Y. Lincoln (Eds.), The Handbook of Qualitative Research (pp. 509-535). Thousand Oaks, CA: Sage publications.

Choi, J.-W. (2007). Governance Structure and Administrative Corruption in Japan : An Organizational Network Approach. Public Administration Review, 67(5), 930-942. Clegg, S. R. (1989). Frameworks of Power. In SAGE Publications. 
https://doi.org/10.2307/1962898

Davenport, S., \& Leitch, S. (2005). Circuits of power in practice: Strategic ambiguity as delegation of authority. Organization Studies, 26(11), 1603-1623. https://doi.org/10.1177/0170840605054627

De Klerk, J. J. (2017). “The Devil Made Me Do It!” An Inquiry Into the Unconscious “Devils Within" of Rationalized Corruption. Journal of Management Inquiry, 26(3), 254-269. https://doi.org/10.1177/1056492617692101

Dobos, N. (2017). Networking, Corruption, and Subversion. Journal of Business Ethics, 144(3), 467-478. https://doi.org/10.1007/s10551-015-2853-4

Eisenhardt, K. M. (1989). Building Theories from Case Study Research. The Academy of Management Review, 14(4), 532-550.

Eisenhardt, K. M., \& Graebner, M. E. (2007). Theory building from cases: Opportunities and challenges. Academy of Management Journal, 50(1), 25-32.

https://doi.org/10.5465/AMJ.2007.24160888

Fath, S., \& Kay, A. C. (2018). "If hierarchical, then corrupt": Exploring people's tendency to associate hierarchy with corruption in organizations. Organizational Behavior and Human Decision Processes, 149, 145-164. https://doi.org/10.1016/j.obhdp.2018.10.004

Fiske, A. P. (1992). The four elementary forms of sociality: Framework for a unified theory of social relations. Psychological Review, 99(4), 689-723. https://doi.org/10.1037/0033295X.99.4.689

Fiske, A. P. (2004). Four modes of constituting relationships: Consubstantial assimilation; space, magnitude, time, and force; concrete procedures; abstract symbolism. In Haslam (Ed.), Relational models theory (pp. 77-162). Psychology Press.

Fleming, P., \& Spicer, A. (2014). Power in Management and Organization Science. Academy of Management Annals, 8(1), 237-298. https://doi.org/10.1080/19416520.2014.875671 
Glaser, B. G., \& Strauss, A. L. (1967). The Discovery of Grounded Theory Strategies for Qualitative Research. Chicago: Aldine.

Graaf, G. De. (2007). Causes Of Corruption: Towards a Contextual Theory of Corruption. Public Administration Quarterly, 31(1), 39-86.

Heath, C., Hindmarch, J., \& Luff, P. (2010). Video in Qualitative Research: Analysing Social Interaction in Everyday Life. London: SAGE.

Husted, B. W. (1994). Honor among thieves: a transaction-cost interpretation of corruption in third world countries. Business Ethics Quarterly, 4(1), 17-27. https://doi.org/10.2307/3857556

Jancsics, D., \& Jávor, I. (2012). Corrupt Governmental Networks. International Public Management Journal, 15(1), 62-99. https://doi.org/10.1080/10967494.2012.684019 Jávor, I., \& Jancsics, D. (2013). The Role of Power in Organizational Corruption: An Empirical Study. Administration and Society, 48(5), 527-558. https://doi.org/10.1177/0095399713514845

Jia, N. (2018). The "Make and/Or Buy" Decisions of Corporate Political Lobbying: Integrating the Economic Efficiency and Legitimacy Perspectives. Academy of Management Review, 43(2), 307-326. https://doi.org/10.5465/amr.2016.0148

Khatri, N., Tsang, E. W. K., \& Begley, T. M. (2006). Cronyism: a cross-cultural analysis. Journal of International Business Studies, 37(1), 61-75. https://doi.org/10.1057/palgrave.jibs.8400171

Kim, S.-J., \& Lee, J. (2019). A Percolation-Like Process of Within-Organization Collective Corruption: A Computational Approach. Business \& Society, 000765031983163. https://doi.org/10.1177/0007650319831630

Lange, D. (2008). A Multidimensional Conceptualization of Organizational Corruption Control. The Academy of Management Review, 33(3), 710-729. 
https://doi.org/10.5465/AMR.2008.32465742

Lawrence, T. B., \& Suddaby, R. (2006). Institutions and institutional work. In S. Clegg, C.

Hardy, T. B. Lawrence, \& W. R. NORD (Eds.), Handbook of organization studies (2nd ed., pp. 215-254). London: Sage.

Lazzarini, S. (2011). Capitalismo de Laços: Os donos do Brasil e suas conexões. Retrieved from

http://scholar.google.com/scholar?hl=en\&btnG=Search\&q=intitle:Capitalismo+de+Laço s\#7

Lemarchand, R., \& Legg, K. (1972). Political Clientelism and Development: A Preliminary Analysis. Comparative Politics, 4(2), 149-178.

https://doi.org/10.1146/tnnorcvjoc.012809.102609

Lukes, S. (1974). Power: A Radical View. https://doi.org/10.1007/978-1-349-02248-9

Moliterno, T. P., \& Mahony, D. M. (2011). Network theory of organization: A multilevel approach. Journal of Management, 37(2), 443-467.

https://doi.org/10.1177/0149206310371692

Morgan, G. (1986). Images of Organizations. Beverly Hills: Sage publications.

Nelson, J. S. (2017). The Corruption Norm. Journal of Management Inquiry, 26(3), 280-286. https://doi.org/10.1177/1056492616675415

Nielsen, R. P. (2003). Corruption Networks and Implications for Ethical Corruption Reform. Journal of Business Ethics, 42(2), 125-149. https://doi.org/10.1023/A:1021969204875

Nunes, E. de O. (2003). A gramática política do Brasil: clientelismo e insulamento burocrático (3rd ed.; J. Zahar, Ed.). Retrieved from https://books.google.com/books?id=FdiLI_K8TkMC\&pgis=1

Nyaga, G. N., Lynch, D. F., Marshall, D., \& Ambrose, E. (2013). Power Asymmetry, Adaptation and Collaboration in Dyadic Relationships Involving a Powerful Partner. 
Journal of Supply Chain Management, 49(3), 42-65. https://doi.org/10.1111/jscm.12011

Nye, J. . S. . (1967). Corruption and Political Development: A Cost-Benefit Analysis. The American Political Science Review, 61(2), 417-427.

Odebrecht. (2018). Jornada da Transformação. Retrieved from

https://www.odebrecht.com/pt-br/a-odebrecht/jornada-da-transformacao

Pagès, M., Gaulejac, V. De, Bonetti, M., \& Descendre, D. (1998). L'emprise de l'organisation (1st ed.). Paris: Desclée de Brouwer,.

Palmer, D., \& Maher, M. W. (2006). Developing the process model of collective corruption. Journal of Management Inquiry, 15(4), 363-370.

https://doi.org/10.1177/1056492606295090

Pinto, J., Leana, C. R., \& Pil, F. K. (2008). Corrupt organizations or organizations of corrupt individuals?Two types of organizational-level corruption. Academy of Management Review, 33(3), 685-709. https://doi.org/10.5465/AMR.2008.32465726

Reeves-Latour, M., \& Morselli, C. (2017). Bid-rigging networks and state-corporate crime in the construction industry. Social Networks, 51, 158-170.

https://doi.org/10.1016/j.socnet.2016.10.003

Rêgo, B. F. S., Dib, L. A. R., \& Bemvindo, B. (2016). A Perspectiva de Redes na Internacionalização de Empresas Brasileiras de Construção Civil: O Caso Vale e BNDES em Moçambique. Revista Ibero-Americana de Estratégia, 15(03), 53-69. https://doi.org/10.5585/riae.v15i3.2359

Roniger, L. (1987). Caciquismo and Coronelismo : Contextual Dimensions of Patron Brokerage in Mexico and Brazil. Latin American Research Review, 22(2), 71-99.

Rosenblatt, V. (2012). Hierarchies, Power Inequalities, and Organizational Corruption. Journal of Business Ethics, 111(2), 237-251. https://doi.org/10.1007/s10551-012-1204$\mathrm{y}$ 
Schubert, T. W. (2005). Your Highness: Vertical Positions as Perceptual Symbols of Power. Journal of Personality and Social Psychology, 89(1), 1-21.

https://doi.org/10.1037/0022-3514.89.1.1

Schubert, T. W., Waldzus, S., \& Seibt, B. (2008). The Embodiment of Power and

Communalism in Space and Bodily Contact. In G. R. Semin \& E. R. Smith (Eds.),

Embodied Grounding (pp. 160-183). https://doi.org/10.1017/CBO9780511805837.008

Shapira, R. (2016). Reputation through Litigation: How the Legal System Shapes Behavior by Producting Information. Washington Law Review, 91(3), 60.

Strauss, A. L. (1987). Qualitative analysis for social scientists. World, 1, 319. https://doi.org/10.1017/CBO9780511557842

Sturm, R. E., \& Antonakis, J. (2015). Interpersonal Power: A Review, Critique, and Research Agenda. Journal of Management, 41(1), 136-163.

https://doi.org/10.1177/0149206314555769

Suddaby, R. (2006). What grounded theory is not. Academy of Management Journal, 49(4), 633-642. https://doi.org/Editorial

Tenbrunsel, A. E., \& Messick, D. M. (2004). Ethical fading: The role of rationalization in unethical behavior. Social Justice Research, 17(2), 223-236.

Trasnparency international. (2017). Brazil: Open Data Just Made Investigating Corruption Easier. Retrieved from Trasnparency international website:

https://www.transparency.org/news/feature/brazil_open_data_just_made_investigating_ corruption_easier

Valente, R. (2016). Escândalos pré-Lava Jato não tiraram Odebrecht do poder. Estadão. Retrieved from http://www1.folha.uol.com.br/poder/2016/12/1842493-escandalos-prelava-jato-nao-tiraram-odebrecht-do-poder.shtml

Warburton, J. (2013). Corruption as a social process: from dyads to networks. In P. Larmour 
\& N. Wolanin (Eds.), Corruption and Anti-Corruption (pp. 221-237). ANU Press.

Weber, R. (2011). The right to be forgotten: more than a pandora's box? Journal of Intellectual Property, Information Technology and E-Commerce (JIPITEC), 2(2), 120130.

Yin, R. K. (2003). Case Study Research Design and Methods (3rd ed.). Thousand Oaks, CA: Sage Publications.

Yu, K. H., Kang, S. D., \& Rhodes, C. (2018). The Partial Organization of Networked Corruption. Business and Society. https://doi.org/10.1177/0007650318775024

Zyglidopoulos, S. C. (2016). Toward a Theory of Second-Order Corruption. Journal of Management Inquiry, 25(1), 3-10. https://doi.org/10.1177/1056492615579914

Zyglidopoulos, S. C., \& Fleming, P. J. (2008). Ethical distance in corrupt firms: How do innocent bystanders become guilty perpetrators? Journal of Business Ethics, 78(1-2), 265-274. https://doi.org/10.1007/s10551-007-9378-4

Zyglidopoulos, S. C., Hirsch, P., Martin de Holan, P., \& Phillips, N. (2017). Expanding Research on Corporate Corruption, Management, and Organizations. Journal of Management Inquiry, 26(3), 247-253. https://doi.org/10.1177/1056492617706648 